\title{
Analysis of Radar Images of Angkor, Cambodia
}

\author{
Anthony Freeman ${ }^{1}$, Scout Hensley ${ }^{1}$ and Elizabeth Moore ${ }^{2}$ \\ $1_{\text {Jet Propulsion Laboratory, California Institute of Technology }}$ \\ 4800 Oak Grove Drive, Pasadena, California 91109 \\ Tel: (818) 3541887 Fax: (818) 3935285 \\ e-mail: tony.freeman @jpl.nasa.gov \\ 2University of London, School of Oriental and Asian Studies, \\ Art and Archaeology Department
}

\begin{abstract}
During the 1996 AIRSAR Pacific Rim Deployment, data were collected over Angkor in Cambodia. The temples of Angkor date the succession of cities to the 9th-13th century $A D$, but little is known of its prehistoric habitation. A related area of archaeological debate has been the origin, spiritual meaning and use of the hydraulic constructions in the urban zone. The high resolution, multi-channel capability of AIRSAR, logether with the unprecedentedly accurate topography provided by TOPSAR, offer identification and delineation of these features. Examples include previously unrecorded circular earthworks around circular village sites, detection of unreconded earthwork dykes, reservoirs and canal features, and of temple sites located some distance from the main temple complex at Angkor

\section{INTRODUCTION}

Imaging radar is a fairly new tool as far as its use in archaeology is concerned. There are relatively few examples of the application of imaging radar to sites of archaeological interest, all but Angkor being based on spaceborne rather than airborne images. The discovery, using data from the Spaceborne Imaging Radar-C (SIR-C) of a remnant earthwork from an earlier 'Great Wall of China', and an ancient canal near the Old Silk Road in China, being notable examples. Imaging radar data from the SIR-C mission was also used to help confirm an earlier discovery of tracks leading to the now famous site of the 'lost city' of Ubar in Oman. TThese examples can be seen at the NASAJPL section on radar archaeology at their web site, at URL: http://www.jpl.nasa.gov/radar/sircxsar/archaeology.huml].

This paper will focus on our analysis of the imaging

ground verification of some of the features visible in the rader data.

\section{THE RADAR DATA}

The NASA/JPL TOPSAR instrument flown on board a DC-8 aircraft uses radar interferometry to generate very accurate high resolution topographic maps and imagery. This is especially important for areas such as Angkor where relief on a very small height scale (a few tens of meters), can control the flow of water over large areas of ground. Radar interferometry should work very well in such areas, allowing small-scale height variations to be mapped with high accuracy. The Angkor region data were collected during the 1996 PaxRim Deployment and processed to ground pixel postings of 5 and 10 meters. The height accuracy for the Angkor elevation data varies between 0.5 to $2 \mathrm{~m}$ depending on where the elevation is measured. Previous maps of the area have contours at only 5$10 \mathrm{~m}$ intervals. The TOPSAR instrument also measures $\mathrm{C}$ Band backscatter and this is used to produce corresponding images to the elevation data. L- and P-Band polarimetric dea were also collected at the same time as the TOPSAR data The L- and P-Band data allow interpretation of land cover type. particularly the differentiation of forestedinon-forested areas.

Complete polarimetric and interferometric mosaics were used to view the whole data set and begin a comparative inventory of features. The data consists of three $10 \times 60$ kilometre runs, two oriented east to west across central Angkor and one oriented southwest to northeast beginning just west of the West Baray, which is a $8 \mathrm{~km}$ long rectilinear reservoir constructed in the 12 th Century $\mathrm{AD}$ (see Figure 1).
\end{abstract} radar data in support of archaeological studies and subsequent 


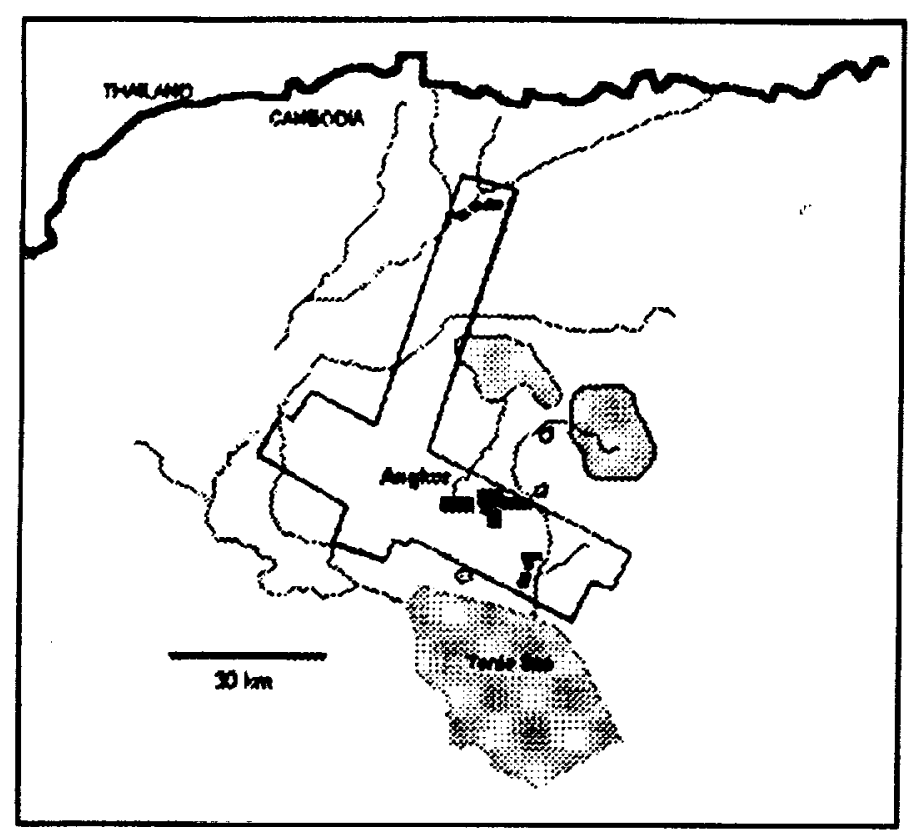

Figure 1: The area covered during the AIRSAR data acquisition, with the Ton Le Sap at the bottom, the Thai border at the top, and Angkor in the center of the map.

\section{THE STUDY SITE}

Amongst the classic monumental cities of Southeast Asia, 9th-13th century AD city of Angkor is unique in two respects. The first, and most well known, is the quantity of monumental temples, both the concentrated succession of cities at Angkor, and the vast distribution of smaller cities and villages in Cambodia and Thailand which comprised the Angkorean empire. The second is the degree to which the ancient Khmer manipulated the natural bydrology to conserve water during the November-April dry season and control the flooding during the monsoonal months, May-October. The construction of water management structures was part of the foundation of each new village or city, equal in ritual significance to the construction of the temple. ${ }^{1}$

Angkor is located near the present town of Siem Reap in northern Cambodia. South of Angkor and Siem Reap is the Tonle Sap or Great Lake, one of the natural wonders of Southeast Asia. The lake doubles in size during the six months of rain. It acts as a relief valve for the overburdened drainage of the Mekong River into the South China Sea. This seasonal inundation brings an abundanoe of fish, the main protein in the local diet. The receding floodwaters are captured by dikes north of the lakeshore, supplying a reliable means to begin the year's wet rice cultivation. The Tonle Sap is a striking feature of the Siem Reap floodplain, and a major factor in setulement of the region. It, along with centrally controlled irrigation and Hindu cosmology have been used to explain the urban phenomenon we call Angkor. However, it was water to north of the city that was exploited and controlled by the water management structures of Angkor. The manmade alterations included circular and rectilinear moats, canals, rectangular tanks, and dikes used in various ways as above ground catchment devices. These lie low on the flat terrain, stretching across the landscape, in contrast to the tall temple-mountains built to house the Hindu deities.

The rectilinear features of Angkor are very striking in all forms of imagery of the area taken from above, including radar data. The barays, large artificial basins laid out inside dikes above ground level, are particularly notable, the largest stretching 8 kilometers east-west. There is a network of foder canals and moats, and of course, the remaining temples, such as the 12th century AD Angkor Wat, set within a 200 meter wide moat. It is clear from decades of investigations by archaeologists that the Khmer controlled water on a large scale; they not only built moats and reservoirs, but diverted and canalized rivers.

The mosaic encompasses some 1500 square kilometers, from the East Baray Damdech canal 30 kilometers east of Angkor, then northwest, ending 25 kilometers south of the Thai border. There are manmade features requiring further investigation in each portion of the mosaic. For example, to the east is a trapezoidal reservoir fording an old riverbed adjacent to the kilns of Setthnikum. The moat of the 11th century temple of Chau Srei Vibol cuts across the edge of the rounded terrace east of the Stung Roluos. The mosaic puts the layout and chronology of Hariharâlaya in a wider context, one that includes constructions on the opposite bank of the river Roluos, an elevated area within Prei Monti and the villages of Phum Kouk Srok and Phum Boeng further south.

Manmade alterations continue in the northern raches despite a rise in elevation, from 20 to 222 metres. Some manmade features may be attributed to the 9-13th century $A D$ Angkor period. Vestiges of curvilinear moats and earthworks around the circular mounds are presumed to pre-date this era. Additional rectilinear features such as temples and tanks are visible on the AIRSAR data that to not appear in earty twentieth century French inventories. American and Vietnamese maps 1:50,000 maps from the 1970's and 1980's become increasingly poor in the northem portions of the study area."

The southem part of the AIRSAR run begins at Nôkôr Pheas (13.36n $\times 103.43 \mathrm{e}$ ). The northern end is along the Stung Srêng midway between Samrong and Anlong Veng (14.07n $\times 103.48 \mathrm{e})$. Much of the study area is in the present day province of Oukar Meanchay. The data provides unique cover of a litule-known region. The thick forest offers 
comparative material for the wooded zones around Angkor, and an opportunity to use the canopy penetration of the P-Band. Manmade water management features extend to the limit of the AIRSAR cover. For example, rectilinear structures are visible in a triangle between the Stung Sreng and a stream flowing down from the northwest, the $O$ Ambok. This region has no temples or features recorded on maps or in inventories. The features appear on shaded relief from the DEM and P-Band amplitude phase.

One of the results of the study was the identification of a temple found by examining the shaded relief images generated from the interferometrically derived beight map (see Figure 2). The temple is not found on any existing maps but was confirmed to exist by a villager, who referred to it as Prasat Sman Teng. It was not possible to go to the temple due to its location in territory controlled by the Khmer Rouge.

The temple enclosure at Prasat Sman Teng is tlanked on the northeast by a rectangular tank, another water storage device. To the southwest a linear feature may be a dike for water control or, as suggested by the shaded relief image, may be part of a larger enceinte around the temple. The Sman Teng tank is roughly the same length (500 metres) as that at Vatt Prasat Thnong at Phum Mokak. It is notable that some temples in this zone are oriented approximately northeast southwest while others are east west

This northern zone also links Angkor to the Khmer remains of Northeast Thailand. Angkor was a powerful regional centre, a city of the north with minimal antecedents in the cultures of southern Cambodia. In both contexts, northwest Cambodia is vital. The ancient Khmer changed the land, and not just at Angkor. At every opportunity, in seemingly remote corners, they constructed mechanisms to control and conserve water. The radar data highlights these water-related constructions and areas of the terrain.

\section{SUMMARY}

The AIRSAR Cambodia data provides an overview, a unique combination of breacth and detail that is belpful for archaeologists in order to comprehend the extent and motivation for the ransformation of the ancient Khmer landscape. A recent field visit answered some of the questions raised by the interpretation of the mosaics. The next phase of this project will continue to address archaeological questions and also refine our interpretation of the Cambodian landscape as sensed by the AIRSAR equipment

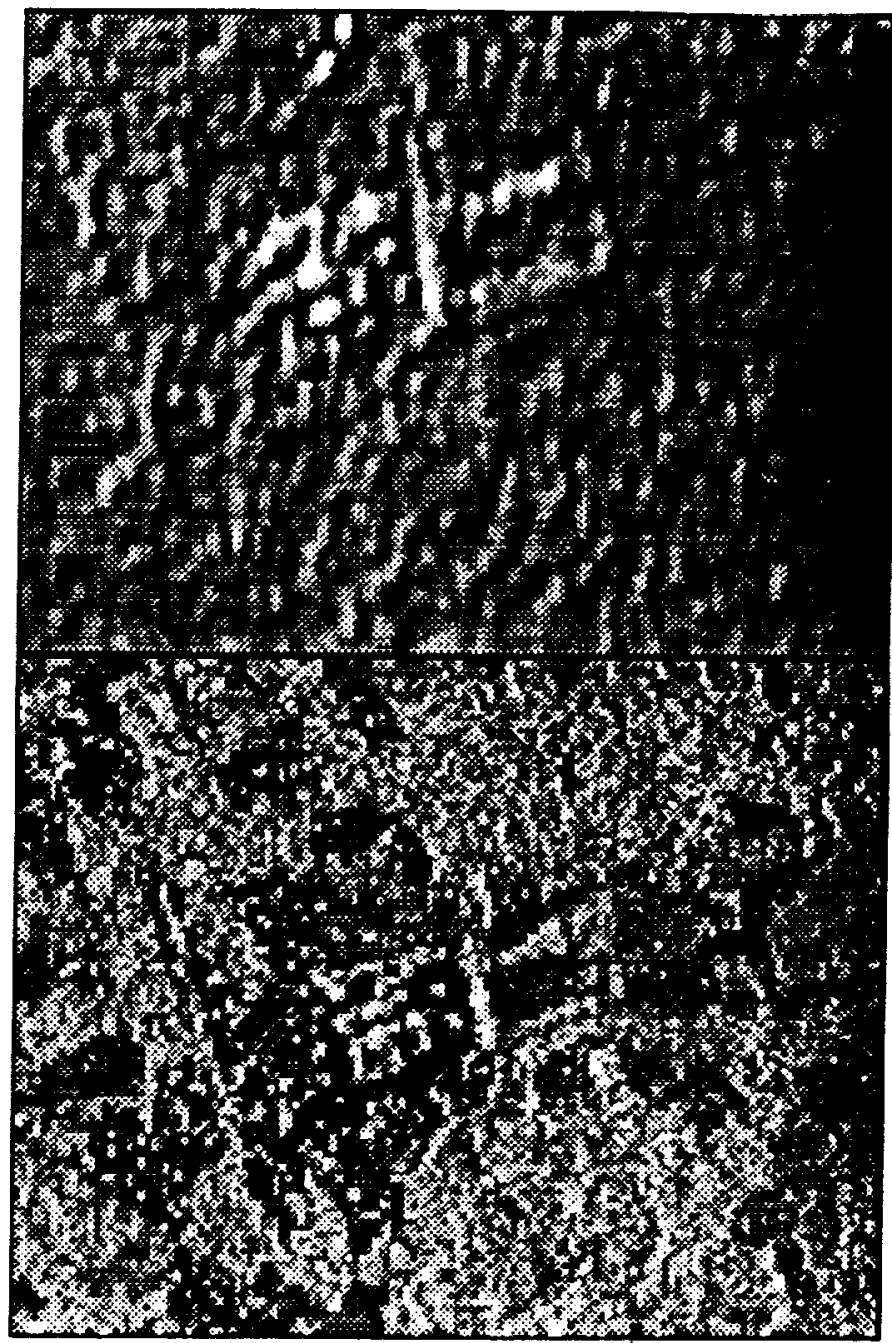

Figure 2: Prasat Sman Teng as Shaded Relief (top) and as a composite PLC greyscale image (bottom).

\section{ACKNOWLEDGMENTS}

Part of the research described in this paper was carried out by the Jet Propulsion Laboratory, Califormia Institute of Technology, under a contract with the National Aeronautics and Space Administration. The authors would like to thank Tep Va tho and her colleagues at APSARA for their lind assistance. 